\title{
Laurence Sterne and the Roots of Postmodern Metafiction
}

\author{
Nino Jincharadze \\ Batumi Shota Rustaveli State University, 6010, 35, Ninoshvili st, Batumi, Georgia \\ Tel: +995-579-880506 E-mail: nino.jincharadze@ymail.com
}

\begin{abstract}
Postmodern novel is the latest stage of multilayer and complex process of the novel genre development. Therefore, it is subject of great interest in literary theory of new millennium to explore the characteristics and roots of postmodern attitude to the narrative. The actuality of the research is determined by the fact that postmodern novel is reflection of modern society perception and its genuine model. The aim of the article is to explore the roots of metafiction, that is inseparable element of postmodern novel and one of the main indicators of its development. According to the study, we have used the following methods: description and comparison. The research has shown, that the origin of metafictional narrative, in its postmodern form, emerges in Laurence Sterne's innovative novel "The Life and Opinions of Tristram Shandy, Gentleman" more than two centuries earlier of its intense flourish in literature. Talking directly to the reader, acknowledging the fact that story is a fiction and is read by a reader, appearance of an author as a character in the story, rejection of traditional plot, discussing methods of storytelling within the narrative process etc. that are some of the important traits of metafiction, are commonly used by Sterne in his novel, that proves him one of the founders of metafictional technique of narrative in literature.
\end{abstract}

Key words: metafiction, postmodern novel, narrative technique, reader oriented narrative, plotless

DOI: $10.7176 / \mathrm{JLLL} / 55-10$

Publication date: April $30^{\text {th }} 2019$

\section{Introduction}

Metafictional technique of narrative has become important element of modern literature and accordingly is a subject of permanent discussions in literary theory. Many postmodern authors have performed interesting experiments on narrative mode, changing the traditional technique of storytelling, making the plot structure unconventional, blurring the line between fiction and reality, inviting a reader in process of narrative permanently acknowledging his presence. Metafictional technique belongs to postmodernism, however, may its origin be assigned to the century of postmodernism or not? Through the analyses of the literature of previous periods we come to the conclusion that the answer to this question is negative, since the embryo of metafiction can be found in Geoffrey Chaucer's "Canterbury Tales", Miguel de Cervantes's "Don Quixote" and is especially elaborate in Laurence Sterne's “The Life and Opinions of Tristram Shandy, Gentleman”. Sterne's writing technique, his permanent dialogue with a reader, explanations and instructions about novel writing methods and reasons within the storytelling, extraordinary plot without development, was unique for his period. Time chronology and dimensions are chaotically disordered, function of graphic details is much more than of simple illustrations. Therefore, this extraordinarily innovative novel predicts nearly all the characteristics of postmodern metafiction of the $20^{\text {th }}$ century almost 2 centuries early. 


\section{Origin of the term and general characteristics of metafiction}

Novel, that is brainchild of modern era and is labeled as "postmodern", rejects general truths, destroys linear and ordered narrative, traditional plot and technique of storytelling, uses parody, absurd, allusions. It is self-reflexive, fragmentary and hybrid. Emphasizes importance of visualization in process of narration and perception, boundary between reality and fiction is blurred, the role of a reader is completely changed.

The fact, that nearly all the aspects listed above may be considered part of metafictional technique, makes it clear that it's impossible to discuss postmodern novel without metafiction. The term was first coined by William $\mathrm{H}$. Gass in his essay "Philosophy and the Form of fiction", in which he depicts metafiction as fiction about fiction and assumes that many of the so-called anti-novels are really metafictions. This is a text, the status of which is only a text, story within a story, where the process of creation and perception is the most important and as John Barth writes, it imitates not real world but the novel itself.

\section{Vague reality and reader acknowledgement}

In metafictional narrative, it's often difficult to distinguish real characters or an author and fictional ones. As it is in case of Curt Vonnegut's "Slaughterhouse-five "narrator. Is he a person who really went through a war? He says: "All this happened, more or less. The war parts, anyway are pretty much true." (Vonnegut, 2000:3). Who is the narrator? Is he Vonnegut himself or the protagonist? Is it fiction or are there particles of reality? The narrator starts storytelling with this hint of "more or less" reality and leaves a reader under permanent doubt. Likewise, we wonder if Tim O'Brian is a real narrator in his novel "Things they carried" taking into consideration the fact that he really fought in Vietnam war. We feel uncertainty about it as the words of the narrator are declaration of the vague reality: „I want you to feel what I felt. I want you to know why story-truth is truer sometimes than happening-truth" (O’Brian, 1990: 179).

In metafictional novel the function of narrator is no longer passive. He acts as co-author of the fictional text. Therefore, if a reader doesn't get involved in a story creation and perception, if he doesn't follow the rules stated by the narrator, if he doesn't play his role appropriately, the text will lose its sense and turn into chaos. Accordingly, dialogue is an important tool of metafictional narration and often contains discussion of writing structure, plans and technique that narrator intends to use. It seems the storytelling is based on agreement between a reader and an author (or/and narrator) since the narrator permanently discusses and explains his narrative technique and gives directions, never forgetting the existence of a recipient. In his extraordinary novel "House of Leaves" (2000) Mark Z. Danielewski uses the same technique of dialogue:

"So you see from my perspective, having to decide between an old man $\mathrm{Z}$ and his story is an artificial, maybe even dangerous choice, and one I'm obviously not comfortable making. The way I figure it, if there's something you find irksome - go ahead and skip it. I couldn't care less how you read any of this. His wandering passages are staying, along with all his oddly canted phrases and even some warped bits in the plot (Danielewski, 2000:31)".

The narrator gives directions to the reader and dictates the rules of reading, realizing the impossibility of proper perception without these prior instructions and permanent dialogue.

The presence of a reader is sometimes not so obvious and seems more obscure, yet it is almost permanently felt. Like it is in case of Pynchon's "The Crying of Lot 49". Pynchon uses less eye-catching method of acknowledgement of a reader:

"WASTE? Oedipa wondered. Beneath faintly in pencil, was a symbol she'd never seen before, a loop, triangle and trapezoid, thus: 


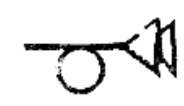

(Pynchon, 1986:38)

Who is "thus" dedicated to? The moment the narrator uses this expression reveals the presence of a reader who is referred to in this hidden dialogue and is expected to look at the sign. Therefore, verbal description of a symbol is not the only way of storytelling but physical form of the text can also serve as one of methods of depiction.

\section{Some characteristics of metafictional plot}

The technique of a dialogue is often necessary to give some explanations to seemingly chaotic plot, that is destruction of traditional attitudes to linear, logically arranged storytelling. This is one of the important traits of metafictional narrative. The reader's expectations about story with culmination, emotions, happy or tragic ending are destroyed through the narrative and especially in the end, as the last part of the metafictional novel generally reveals, the impossibility of finding answers, since they mean nothing, emphasize absurdity of being or simply don't exist. Like it is in "Slaughterhouse-five", the last phrases of the novel are demonstration of this absurdity of life and therefore absurdity of logical narrative.

"Birds were talking. One bird said to Billy Pilgrim, 'Poo-tee-weet?"” (Vonnegut, 2000:177). Despite the fact that from the beginning of the novel narrator predicts this ending phrase, it is still unexpected because of its absurdity. Pynchon goes even further and presents the plot that seems to be adventure, exciting, mysterious crime story, that is being investigated by the main character. However, in the end he nearly cuts the storytelling and leaves it allegedly unfinished.

"Oedipa sat alone, toward the back of the room, looking at the napes of necks, trying to guess which 19 one was her target, her enemy, perhaps her proof.(...) She heard a lock snap shut; the sound echoed a moment. (...) The auctioneer cleared his throat. Oedipa settled back, to await the crying of lot 49." (Pynchon, 1986:152).

\section{Sterne's experiments on narrative technique}

Looking back to the literary background of $18^{\text {th }}$ century, it is obvious that character of Sterne's works is extraordinarily innovative. Sterne destroyed the conventions of novel writing technique and created the novel with a completely new attitude to the storytelling - a novel without linear plot, without culmination, drama, logical ending, without ordered chronology and narrative lines.

Dialogue with a reader is important part of Sterne's narrative. The "dialogue" is not the term chosen accidentally, as a reader is not only asked questions referred to, given explanations, criticized or praised, but he or she gives answers that are meant in the process of the narrative:

„- - How could you, Madam, be so inattentive in reading the last chapter? I told you in it, That my mother was not a papist.-Papist! You told me no such thing, Sir. - Madam, I beg leave to repeat it over again, that I told you as plain, at least, as words, by direct inference, could tell you such a thing.- - Then, Sir, I must have miss'd a page."(Sterne, 2003:48). 
Narrator often dictates and explains rules of reading and perception methods of the novel, that is also important trait of metafiction.

„-And therefore, I beg, Madam, when you come here, that you read on as fast as you can, and never stop to make any inquiry about it.“(Sterne, 2003:57)

The use of such dialogues is quite intense in the novel. It alters time and dimensions of narrative permanently, distracts reader's attention from the plot and as a result, the novel that starts with conception of the main character and therefore creates the impression that we will read a story of Tristram Shandy, full of exciting adventures, ends with absolutely unexpected ending:

"L- - d! said my mother, what is all this story about? - A COCK and a BULL, said Yorick - And one of the best of its kind, I ever heard" (Sterne, 2003:526).

"A cock and a Bull” expression that originates from French 'coq-a-l'âne' and is defined as "An incoherent story, passing from one subject to another", is the symbol of Sterne's narrative style as well as metafictional narrative style of postmodern novels.

\section{Conclusion}

The analyses of Tristram shandy reveals the evident roots of metafictional technique of narrative in Sterne's novel. The study of these roots is important for history of novel development generally and specifically for the development of postmodern metafictional mode. Sterne's style, that was considered weird, taking into consideration the literary background of the $18^{\text {th }}$ century, predicted nearly all the main elements of postmodern metafiction: reader oriented narrative, disordered chronology and unconventional plot, blurred line between reality and fiction, as well as between author and narrator, discussion of novel writing within the narration. This fact proves that one of the true originators of metafiction in literature lived much earlier than late $20^{\text {th }}$ century.

\section{References:}

1. Danielewski, M.Z (2000), "House of Leaves", Random House

2. O’Brien, T. (1990), “The Things They Carried”, Mariner Books, Boston, New York

3. Pynchon, T (1986), "The Crying of Lot 49” The library of congress

4. Sterne L. (2003), „The Life and Opinions of Tristram Shandy, Gentleman, Penguin Books, London

5. Vonnegut K. (2000), "Slaughterhouse-five, or The Children's Crusade: A Duty-Dance with Death", Vintage Books 